\title{
The Effect of Service Quality, Product Quality, Experimental Marketing and Location by Intervening Consumer Satisfaction on McDonald's Repurchase Interest in the Green Garden Kedoya Branch.
}

\author{
Lia Amalia, Freddy Pradana Putra \\ ESAUNGGUL UNIVERSITY \\ Email: lia.amalia@esaunggul.ac.id, frdyprdn@gmail.com
}

Received: February $4^{\text {th }} 2021$

Approved: April 25 2021

\begin{abstract}
This study aims to determine the effect of Service Quality, Product Quality, Experiential Marketing and Location as an independent variable by Intervening Consumer Satisfaction on Purchasing Intention as a dependent variable at McDonald's Green Garden Kedoya Branch. The research was conducted in September 2020 and method of analysis used in this research is Path Analysis. The results of this study indicate that service quality has a positive influence on customer satisfaction, while product quality has no effect on customer satisfaction. Experiential marketing has a positive and significant influence on customer satisfaction, as well as location which has a positive influence on customer satisfaction. Service quality does not have a positive effect on repurchase interest, but product quality has a positive and significant impact on consumer repurchase interest. Meanwhile, experiential marketing also does not have a positive influence on consumer Repurchase Interest, location has a positive and significant influence on consumer Repurchase Interest.
\end{abstract}

Keywords : Service Quality, Product Quality, Experiential Marketing, Location, Customer Satisfaction, Repurchase Interest 


\section{Introduction}

The intense competition for customers provides motivation for entrepreneurs to remain disciplined in running a business in the field of product sales. McDonald's Green Garden Kedoya Branch must be able to understand the needs and understand the tastes desired by customers and still have to pay attention to aspects of product quality, service quality, experiential marketing, and location, so that McDonald's Green Garden Kedoya Branch can provide good service satisfaction to its customers. Customers form expectations based on messages received from sellers, other people, friends and other sources of information. If the seller increases a product excessively and the customer cannot feel that satisfaction, then the customer will experience wasted expectations. Companies offer goods or services according to customer needs and desires. The products offered by McDonald's Green Garden Kedoya Branch are expected to be in accordance with the wishes and expectations of customers which will result in purchasing decisions. The higher level of inequality, expectations and quality, the greater the customer dissatisfaction. In increasing customer satisfaction, McDonald's believes that the company is obliged to provide satisfaction to its employees. It is intended that employees provide similar things (service and product quality) to their customers, in order to achieve customer satisfaction. In addition, McDonald's indulges its customers through a delivery order service. McDonald's is ready to deliver its food products to consumers' homes, improve product quality according to consumer interests in the local area, and provide bonuses with unique toys. This is done in order to maintain customer loyalty. If the perceived service is in accordance with the expected service, then the quality of the service concerned will be perceived as good or positive. If the perceived service exceeds the expected service, then the service quality is perceived as ideal quality. Conversely, if the perceived service is worse than the expected service, then the service quality is perceived as negative or bad. Therefore, whether the quality of service is good or not depends on the ability of service providers to consistently meet customer expectations. In addition to the quality of service and products, McDonald's must also pay attention to the location of the company. Determination of location is the main strategy in the retail business. A strategic location will be the opening path that determines the success of a retail business. Many retail entrepreneurs sometimes do not understand the importance of location when opening a retail business, so they do not conduct location surveys and develop the right strategy in selecting the location. Unlike in traditional marketing, companies can get a competitive advantage if they are able to satisfy customers through quality service. In the concept of experiential marketing, companies must compete by creating a satisfying experience, that the company must combine the five basic elements of experiential marketing to detect the purchasing process by consumers. Service quality, product quality, good experiential marketing and a strategic location are very important because of the quality. These products can give a good impression and provide satisfaction to consumers who enjoy McDonald's. Based on the descriptions and reasons of the researchers above, the researcher is interested in conducting research with the analysis of The 
Effect of Service Quality, Product Quality, Experimental Marketing and Location by Intervening Consumer Satisfaction on McDonald's Repurchase Interest in the Green Garden Kedoya Branch.

\section{Literature Review}

Definition of Repurchase Interest

Purchase interest is the stage where consumers form their choice among several brands that are members of the choice set. Then in the end make a purchase at an alternative he likes best or the process that consumers go through to buy a good or service based on various considerations. According to Kotler (2013) purchase interest arises after an alternative evaluation process. In the evaluation process, someone will make a series of choices regarding the product to be purchased on the basis of brand or interest.

Understanding Customer Satisfaction, customer satisfaction is an important factor, especially for service companies. Because for service companies, customer satisfaction is a reference for the company's success in providing services to consumers. To achieve customer satisfaction the company must provide optimal service quality in accordance with consumer expectations. Satisfied consumers will become company consumers and will have a positive impact on the company's survival.

Definition of Service Quality according to Kotler \& Keller (2016) "Service quality is an action or performance that one party can offer to another party which is basically intangible and does not result in any ownership". According to Parasuraman, Zeithaml, and Berry in Sudarso (2016) who argue that "Service quality is a perceived benefit based on consumer evaluation of interactions compared to previously expected benefits".

Definition of Product Quality. The product is the core of a marketing activity because the product is the output or result of one of the company's activities or activities that can be offered to the target market to meet the needs and desires of consumers. Basically, in buying a product, a consumer not only buys the product, but consumers also buy the benefits or advantages that can be obtained from the product he buys. Therefore, a product must have advantages over other products, one of which is in terms of the quality of the product offered. Product quality is one of the keys to competition among business actors that are offered to consumers.

Understanding Experiential Marketing. Experiential marketing is a relatively new concept in the field of marketing management. According to Lee et. al., (2016) experiential marketing as memories or experiences that enter the minds of customers. Experiential Marketing comes from two words, namely experience and marketing. Experience is "experience is a personal event that occurs due to a certain stimulus (for example, provided by the marketer before and after the purchase of goods or services)" (Schmitt, 1999).

Definition of Location. Location is a place to serve consumers, it can also be interpreted as a place to display merchandise (Kasmir, 2016). The definition of location is where the company 
operates or where the company carries out activities to produce goods and services that are of economic importance. Some of the criteria that can be used to assess a strategic location are as follows:a)

\section{Reseacrh Methodology}

This type or research design or research design is quantitative descriptive that uses survey methods. This study examines the effect of service quality, product quality, experiential marketing and location with intervening consumer satisfaction on McDonald's repurchase interest in the Green Garden Kedoya branch. The population size in the study is very large and the number is not known with certainty, so the sample size used according to the number of samples taken was 155 people so that in this study. The technique used in sampling using nonprobability sampling method with purposive sampling technique. The nonprobability sampling method is sampling that does not provide equal opportunities or opportunities for each member of the population to be selected as a sample. The previously known population characteristics, as follows: a. Willing to be a respondent. b. Minimum age of respondents is 17 years. c. Customers of McDonald's Green Garden Kedoya Branch encountered during the study period.

The research model used is as follows:

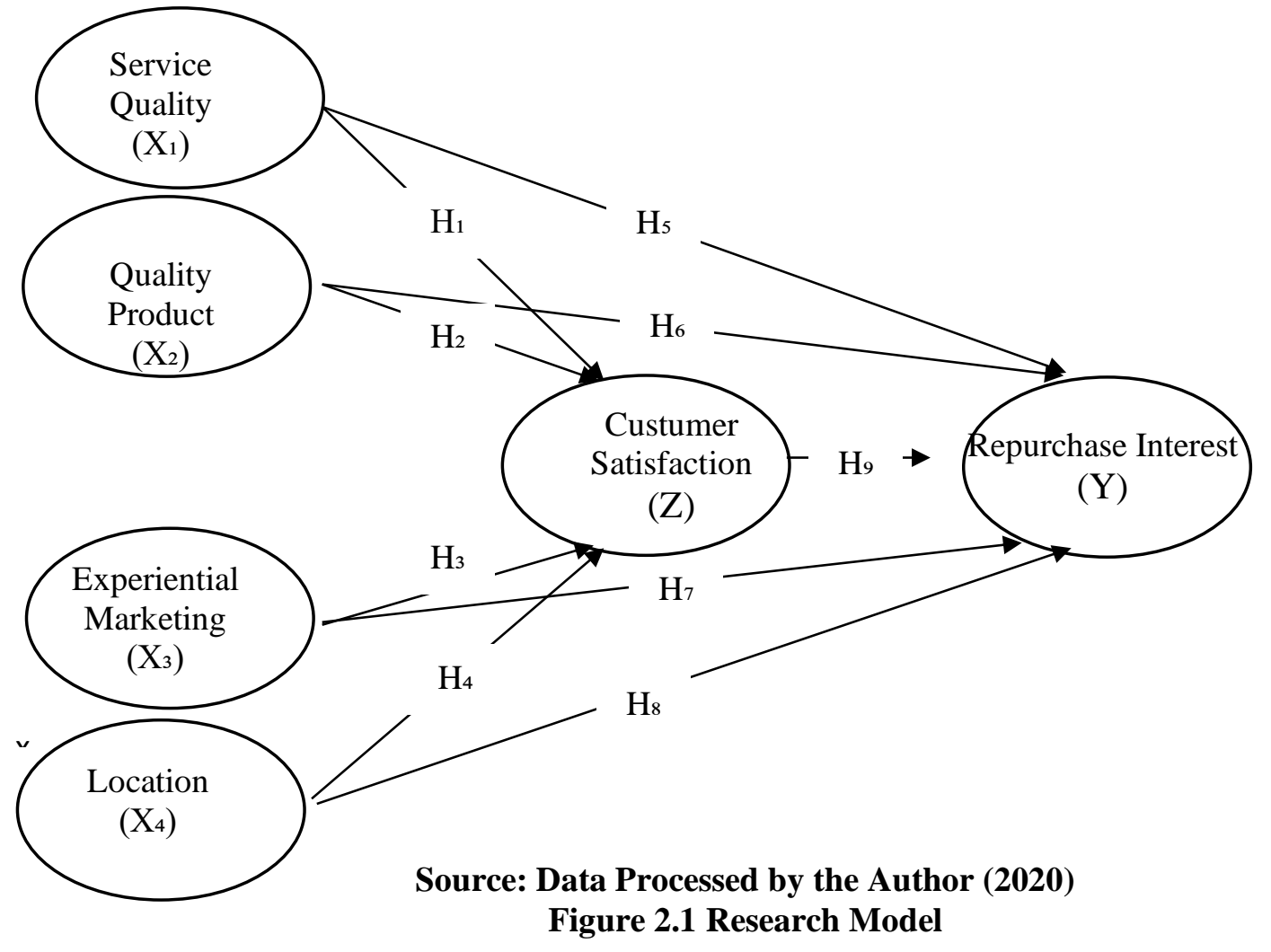

\section{Result}


Tabel 4.1 Influence Calculation Results

\begin{tabular}{|l|l|l|l|l|}
\hline \multirow{2}{*}{ Variabel } & \multirow{2}{*}{$\begin{array}{l}\text { Path } \\
\text { Coefficient }\end{array}$} & Direct & $\begin{array}{l}\text { Indirect Through } \\
\text { Z }\end{array}$ & Total \\
\cline { 3 - 5 } & & & & \\
\hline $\mathrm{X}_{1} \rightarrow \mathrm{Z}$ & 0,081 & & & \\
\hline $\mathrm{X}_{2} \rightarrow \mathrm{Z}$ & 0,003 & & & \\
\hline $\mathrm{X}_{3} \rightarrow \mathrm{Z}$ & 0,330 & & & $-0,213$ \\
\hline $\mathrm{X}_{4} \rightarrow \mathrm{Z}$ & 0,497 & & 0,030 & 0,380 \\
\hline $\mathrm{X}_{1} \rightarrow \mathrm{Y}$ & $-0,243$ & $-0,243$ & 0,001 & $-0,080$ \\
\hline $\mathrm{X}_{2} \rightarrow \mathrm{Y}$ & 0,379 & 0,379 & 0,125 & 0,363 \\
\hline $\mathrm{X}_{3} \rightarrow \mathrm{Y}$ & $-0,205$ & $-0,205$ & 0,188 & \\
\hline $\mathrm{X}_{4} \rightarrow \mathrm{Y}$ & 0,175 & 0,175 & & \\
\hline \multirow{2}{*}{$\varepsilon$} & 0,559 & & & \\
\cline { 2 - 5 } & 0,977 & & & \\
\hline
\end{tabular}

Source: Data processed by researchers 2020

The results of this study explain that there is no positive influence between service quality on customer satisfaction at McDonald's Green Garden branch, which means that most respondents do not have Repurchase Interest due to the quality of service provided by McDonald's Green Garden branch.

Effect of Product Quality on Repurchase InterestThe results of this study explain that there is a positive and significant influence between product quality on consumer repurchase interest in McDonald's Green Garden branch, which means that most respondents have an interest in buying the products offered because of the quality of the products at McDonald's Green Garden branch.The results of this study explain that there is no positive and significant influence between experiential marketing on consumer repurchase interest in McDonald's Green Garden branch, which means that experiential marketing applied by McDonald's Green Garden branch does not affect some respondents to feel an interest in buying.The results of this study explain that there is a positive but insignificant influence between locations on consumer repurchase interest of McDonald's Green Garden branches, which means that the location of McDonald's Green Garden branches can affect some respondents to feel satisfaction, but not significantly.

\section{Conclusions and Recommendation}

After conducting the research, the research results and conclusions that will be described by the researcher after conducting the research are related to service quality, product quality, experiential marketing and location towards repurchase interest through customer satisfaction at McDonald's Green Garden branch, namely: Service quality does not have a positive effect on customer satisfaction, meaning that consumers do not consider the quality of service provided by 
McDonald's Green Garden branch. Service quality of employees of McDonald's Green Garden branch has the ability to respond to customer needs, this means that the quality of service of these employees cannot affect customer satisfaction but with other factors that can make consumers feel satisfied. Product quality does not have a positive effect on customer satisfaction, meaning that consumers do not consider the quality of the product provided by McDonald's Green Garden branch. McDonald's Green Garden branch has a diverse food menu, but this cannot affect customer satisfaction with the exception of other factors that may affect customer satisfaction.

Experiential marketing has a positive and significant effect on customer satisfaction, if the better experiential marketing is given, the higher the customer satisfaction of McDonald's Green Garden branch. Employees provide services according to customer needs. Thus, consumers feel satisfaction because the services that have been previously provided are in accordance with the needs of McDonald's customers, Green Garden's branch. Location has a positive and significant effect on customer satisfaction, if the better the location of McDonald's Green Garden branch, it will increase customer satisfaction. The strategic location of McDonald's Green Garden branch or easy to reach can increase customer satisfaction itself Service quality does not positively influence repurchase interest, meaning that consumers do not consider the quality of service provided by McDonald's Green Garden branch. Service quality of employees of McDonald's Green Garden branch has the ability to respond to customer needs, this means that the quality of service for these employees cannot make consumers feel the interest to buy repeatedly. Product quality has a positive effect on repurchase interest, if the better the quality of the product owned, the consumer's interest will increase to buy repeatedly. McDonald's Green Garden branch has a diverse food menu, so this has influenced consumers to buy McDonald's Green Garden branch products repeatedly. Experiential marketing does not have a positive effect on repurchase interest, meaning that consumers do not consider the experiential marketing provided by McDonald's Green Garden branch. Employees provide services according to consumer needs, but this does not affect consumer interest in buying repeatedly. Location has a positive but not significant effect on repurchase interest, if the better the location of McDonald's Green Garden branch, it will increase consumer interest in buying repeatedly. The strategic or accessible location of McDonald's Green Garden branch can increase consumer interest in purchasing repeatedly. Companies must improve and pay more attention to several things such as employees who do not have individual attention to consumers, taste menus that are not in accordance with consumer expectations, make menu packages that are more economical to reach all economic status of the community and make the parking area for consumer vehicles wider than the current one. For further research, it is expected to add or replace other variables besides service quality, product quality, experiential marketing and location that may have an influence on Repurchase Interest or through customer satisfaction. It is hoped that the next researchers will involve more respondents so that the results can be better in the group of respondents with a larger number. It 
is hoped that the research that has been carried out can be useful for researchers and as a source of knowledge.

\section{References}

Adiwijaya, R. D. 2010. Test of six superior clones of curcuma (Curcuma xanthorrhizaRoxb.) On maximum

vegetative growth on vertisol soil in Sragen district. Thesis. Faculty of Agriculture. Sebelas Maret University. Surakarta.vegetative growth on vertisol soil in Sragen district. Thesis. Faculty of Agriculture. Sebelas Maret University. Surakarta.

Alkilani, Khaled, et al. 2013. The Impact Of Experiential Marketing And Customer Satisfaction On Customer Commitment In The World Of Social Networks. Asian Social Science; Vol. 9, No. 1; 2013.doi: 10.5539 / ass.v9n1p262.

Andriasan Sudarso, 2016, Marketing Management for Hospitality Services, Yogyakarta: Budi UtamaAndi Andika Wirawan, Herman Sjahruddin, Nurlaely Razak (2019). The Effect of Product Quality and

Location on Customer Loyalty through Customer Satisfaction as an Intervening Variable. Journal of Organization and Management

Annisa, A. N., Suwandari, L., \& Adi, P. H. (2019). Analysis of the Influence of Customer Experience, User

Experience, and Barriers to Switching on Repurchase Interest (Study on Go-Jek Consumers in the City of Purwokerto). Sustainable Competitive Advantage-9 (Sca-9), 9 (1), 361-372.

Anitasari, S., Rahayu, N.E., 2005. The Relationship between the Frequency of Brushing Teeth and the Level of Teeth and Oral Hygiene of Public Elementary School Students in Palaran District, Kota Madya Samarinda, Profinsi East Kalimantan. Maj. Ked. Tooth. (Dent. J.). 38 (2): 88 Kotler, Philip and Gary Armstrong. (2016). Marketing Principles. Edii13. Volume 1. Jakarta: Erlangga Ardhana, Oldy. (2010). "Analysis of the Influence of Service Quality, Price and Location on Customer University.

Satisfaction (Study at the Caesar Semarang Workshop). Thesis. Semarang: Diponegoro

Arikunto. 2015. Research Procedures for a Practical Approach, Jakarta: Rineka Cipta.

Armstrong, Kotler 2015, "Marketing an Introducing Prentice Hall twelfth edition", England: Pearson Education, Inc

Asghar Afshar Jahanshahi, Mohammad Ali Hajizadeh Gashti, Seyed Abbas Mirdamadi Khaled Nawaser, \& Seyed Mohammad Sadeq Khaksar. 2011. Study the Effects of Customer Service and Product Quality on International Customer Satisfaction and Loyalty. Journal of Humanities and Social Science. Vol. 1 No. 7; [Special Issue -June 2011

Bae, Eun, S., Cho, SY, Won, Y., D, Lee, S., H, Park, H., J. 2011. A Comparative Study of the Different Analytical Methods for Analysis of S-allyl Cystein in Black Garlic by HPLC. The Journal of LWT Food Science and Technology.

Budi Santoso (2017). The Influence of Product Quality, Price, and Promotion on Purchasing Decisions and

Consumer Satisfaction of Sosro Bottle Tea in Semarang. Management Study Program Scientific Paper Documents - S1 FEB UDINUS 2017. Kotler, Philip, \& Gary Armstrong. (2016). Marketing Principles. Edition 13. Volume 1. Jakarta: Erlangga.

Kotler, Philip and Kevin Lane Keller, 2016. Marketing Management, 15th Edition, Pearson Education, Inc. 
Kustini. (2007). Application of Experiential Marketing. Journal of Business Economics Research. Leni Noviani and Muhadjir Nasir (2012). Analysis of the Effect of Price and Service Quality on Customer Satisfaction at Kita Jaya Laundry. Thesis. Binus University.

Lupiyoadi, \& Hamdani. (2008). Service Marketing Management. Edition 2. Salemba Empat.

Malik, et al, 2012. Impact of Brand Image, Service Quality and Price on Customer Satisfaction in Pakistan

Telecommunication Sector, International Journal of Business and Social Science, Vol. 3, No. 23, December 2012.

Malik Ibrahim and Sitti Marijam Thawil (2019). Effect of product quality and service quality on customer satisfaction. Journal of Management and Business Research (JRMB) Faculty of Economics UNIAT Vol.4, No.1 February 2019: 175 - 182

Maryani, Enok. 2009. Development of a Social Studies Learning Program to Improve Social Skills. Vol. 9.

No.1.

Mitha Alifia Roselina \& Asih Niati (2019). analysis of the influence of product quality, service quality and

promotion on consumer satisfaction Elsa hijab semarang. Scientific Solution Magazine Vol. 17, No. July 3, 2019

Rakhmad Maulana and Imam Hidayat (2017). The Influence of Price, Product Quality, and Word of Mouth

on Purchasing Decisions on Xiaomi Smartphones. Journal of Management Science and Research Volume 6, Number 12, December 2017

Santoso, Singgih. 2017. Mastering Statistics with SPSS 24. Jakarta: PT Alex Media Komputindo.

Schmitt, B. H. 1999. Experiential marketing: How to get customers to sense, feel, think, act and relate to your company and brands. New York: Free Press.

Sugiyono. (2014). Educational Research Methods with Quantitative Approaches, Qualitative, and R \& D. Bandung: Alfabeta.

Sugiyono. (2015). Combination Research Methods (Mix Methods). Bandung: Alfabeta.Sugiyono. (2017). Quantitative Research Methods, Qualitative, and R \& D. Bandung: Alfabeta, CV.

Sujarweni, V. Wiratna. 2015. Cost Accounting. Yogyakarta: New Library Press.

Teddy Chandra and Priyono (2015). Source: The Influence of Location, Products, Promotions, Services with Respect to Consumer Behavior (Studies in the Indo March Raya Darmo Surabaya). Review of European Studies; Vol. 7, No. 12; 2015

Trivilla Purnama Dewi (2017). The effect of price, product quality, and service quality on purchasing decisions for Toyota cars at Nasmoco Mati Yogyakarta. Thesis. Sanata Dharma University.

Wibowo. (2014). Work management . Fourth Edition. Jakarta: Rajawali Press.

Zain, Osman M., and Mohammed Bashir Saidu. (2016). The Customers Satisfaction on Retailers' Brand Products: A Study on Selected Areas in Klang Valley. Procedia Economics and Finance 35 (October 2015): 418-27.

Zeithaml, Valarie A, and Bitner. 2000. Service Marketing 2nd edition: Integrating Customer Focus, New York: Mc Graw Hill Inc. 